\title{
Reduced secretion of parathyroid hormone and hypocalcemia in systemic heterozygous ATP2B1-null hypertensive mice
}

\author{
Yosuke Ehara $^{1} \cdot$ Nobuhito Hirawa $^{2} \cdot$ Kouichiro Sumida $^{1} \cdot$ Akira Fujiwara $^{2} \cdot$ Minako Kagimoto $^{1} \cdot$ \\ Yuki Ooki-Okuyama ${ }^{1} \cdot$ Megumi Fujita $^{1} \cdot$ Mari Katsumata $^{1} \cdot$ Yusuke Kobayashi $^{1} \cdot$ Sanae Saka ${ }^{2} \cdot$ Ikuma Katou $^{3}$. \\ Keisuke Yatsu ${ }^{1} \cdot$ Satoshi Umemura ${ }^{1} \cdot$ Kouichi Tamura $^{1}$
}

Received: 25 December 2017 / Revised: 20 January 2018 / Accepted: 22 January 2018 / Published online: 27 June 2018

(c) The Author(s) 2018. This article is published with open access

\begin{abstract}
The ATP2B1 gene is associated with hypertension. We previously reported that systemic heterozygous ATP2B1-null $\left(\mathrm{ATP} 2 \mathrm{~B} 1^{+/-}\right.$) mice exhibited hypertension due to impaired endothelial nitric oxide synthase (eNOS) activity and decreased nitric oxide (NO) production. The ATP2B1 gene encodes plasma membrane calcium ATPase 1 (PMCA1), which has been thought to regulate only intracellular $\mathrm{Ca}^{2+}$ concentration. However, recently, it has been suggested that ATP2B1 works not only at cellular levels, but also throughout the entire body, including in the calcium metabolism, using small intestinespecific $A T P 2 B 1$ knockout mice. To clarify the roles of $A T P 2 B 1$ in the entire body and the effects of $A T P 2 B 1$ on blood pressure, we examined the alterations of calcium related factors in ATP2 $\mathrm{B} 1^{+/-}$mice. ATP2B $1^{+/-}$mice exhibited hypocalcemia. The expression of $A T P 2 B 1$ in the kidney and small intestine decreased, and hypercalciuria was confirmed in ATP2B $1^{+/-}$mice. The intact-PTH levels were lower, and bone mineral density was increased in these mice. These results suggest that hypocalcemia is mainly a result of inhibited bone resorption without compensation by PTH secretion in the case of $A T P 2 B 1$ knockout. Moreover, NO production may be affected by reduced PTH secretion, which may cause the increase in vascular contractility in these mice. The $A T P 2 B 1$ gene is important for not only intra-cellular calcium regulation but also for calcium homeostasis and blood pressure control.
\end{abstract}

\section{Introduction}

Many studies have reported that the $A T P 2 B 1$ gene is one of the candidate genes for hypertension. We reported the association between high blood pressure and the ATP $2 B 1$ gene in the Japanese population through the Millennium Genome Project [1,2]. Furthermore, the ATP2B1 gene was found to be associated with hypertension in people of European [3] or Korean decent [4], and other populations worldwide [5].

$\triangle$ Nobuhito Hirawa

hirawa@yokohama-cu.ac.jp

1 Department of Medical Science and Cardiorenal Medicine, Yokohama City University Graduate School of Medicine, Yokohama, Kanagawa, Japan

2 Department of Nephrology and Hypertension, Yokohama City University Medical Center, Yokohama, Kanagawa, Japan

3 Department of Molecular Pathology, Yokohama City University Graduate School of Medicine, Yokohama, Kanagawa, Japan
ATP2B1 encodes plasma membrane calcium ATPase 1 (PMCA1). PMCA comprises four different isoforms (PMCA1-4) that are encoded by four independent genes. PMCA1 and PMCA4 are expressed ubiquitously, whereas PMCA2 and PMCA3 are mainly present in neuronal tissue $[6,7]$. PMCA1 plays a role in discharging $\mathrm{Ca}^{2+}$ from the inside to the outside of the cell, and strictly regulates the intracellular $\mathrm{Ca}^{2+}$ concentration $[1,8,9]$.

We previously reported that ATP2B $1^{+/-}$mice exhibited enhanced vasoconstriction and elevated blood pressure, and the phenotype was associated with impaired endothelial nitric oxide synthase (eNOS) activity and decreased nitric oxide (NO) production [10]. In addition, vascular smooth muscle cell-specific $A T P 2 B 1$ knockout mice exhibited increased blood pressure, intracellular calcium concentration and vascular contractility [11], and these mice were highly susceptible to calcium channel blockers [12].

Recently, it was reported that small intestine-specific ATP2B1 knockout mice had decreased bone mineral density without changes in serum calcium concentration [13]. This suggested that $A T P 2 B 1$ works not only at cellular levels, but 
also throughout the entire body, including in bone metabolism.

$\mathrm{Ca}^{2+}$ is one of the most important ions in animals. Calcium plays a crucial role in physiological functions, including cardiac muscle contraction, vascular muscle contraction, bone mineralization, fertilization, synaptic transmission, blood clotting, and neuronal function. Therefore, the calcium balance is tightly regulated by bone metabolism, and reabsorption in the kidney and small intestine, which are controlled by hormones such as parathyroid hormone (PTH) and 1 $\alpha, 25$-hydydroxyvitaminD $\mathrm{D}_{3}$ $\left(1 \alpha, 25-\left(\mathrm{OH}_{2} \mathrm{D}_{3}\right)\right.$ [14]. The effects of $A T P 2 B 1$ on bone metabolism, serum calcium concentration and PTH have not been clarified. In order to confirm the roles of $A T P 2 B 1$ in calcium homeostasis and blood pressure control, we examined alterations in phenotypes of bone, small intestine, kidney and parathyroid gland using ATP2B1 ${ }^{+/-}$hypertensive mice, which demonstrated impaired eNOS activity and decreased NO production in vascular smooth muscle cells.

\section{Methods}

\section{Animal care}

Animals were housed under a 12-h light-dark cycle at $25^{\circ} \mathrm{C}$. Mice were examined at 12-15-weeks of age and fed a normal-salt diet $(0.3 \% \mathrm{NaCl})$ with free access to drinking water. Biochemical analyses were performed on blood samples collected after cardiac puncture under deep anesthesia with intraperitoneal administration of pentobarbital sodium $(32.4 \mathrm{mg} / \mathrm{kg})$. Vital organs were removed after euthanasia. Experiments were conducted under the guidelines for animal experiments set by the Animal Experiment Committee of Yokohama City University School of Medicine.

\section{Generation of systemic heterozygous ATP2B1-null $\left(\right.$ ATP2B1 $^{+/-}$) mice}

$\mathrm{ATP} 2 \mathrm{~B} 1^{+/-}$mice were generated as previously described [10] using the Cre-loxP system because the ATP2B1-null mutant displays embryonic lethality [15]. Tie2 promotor can cause non-cell-specific deletion of floxed alleles through the germ line activation. Normally, two successive rounds of breeding are performed to generate mice carrying two floxed target-gene alleles and a transgene expressing Cre-recombinase tissue-specifically. However, this causes the conversion of the floxed allele to a null allele in the germ line, which is transmitted to offspring, which can result in global deletion irrespective of their Crerecombinase genotype. Therefore, germ-line activation of the Tie 2 promotors can cause non-cell-specific deletion of floxed alleles with a fixed probability [16]. ATP2B $1^{+/ l o x P}$ : Tie2-Cre mice were created by mating ATP2B1 $1^{\text {loxP/loxP }}$ female mice with transgenic mice expressing Cre recombinase under control of the murine Tie2 promotor (Tie2-Cre mice) [17] (B6.Cg-Tg(Tie2-Cre)1Ywa/J, stock No.008863, Jackson Laboratory). ATP2B1 ${ }^{+/ l o x P}:$ Tie2-Cre male offspring were then crossed with ATP2B $1^{\text {loxP/loxP }}$ female mice, and we created systemic heterozygous ATP2B1 null $\left(\mathrm{ATP} 2 \mathrm{~B} 1^{+/-}:\right.$Tie2-Cre $\left.(-)\right)$mice and genetic control $\left(\mathrm{ATP} 2 \mathrm{~B} 1^{+/+}\right.$:Tie2-Cre $\left.(-)\right)$mice. Animals included in this study were $12-15$-week-old $\mathrm{ATP} 2 \mathrm{~B} 1^{+/-}$mice, with $\mathrm{ATP} 2 \mathrm{~B} 1^{+/+}$mice as controls.

\section{Measurement of serum calcium, phosphorous and several calcium regulatory markers}

Serum calcium and phosphorous were analyzed with the 7170 autoanalyzer (SRL, Inc., Tokyo, Japan). Serum intactPTH, fibroblast growth factor 23 (FGF23), and osteocalcin were measured with the ELISA method by MTP-300 MICROPLATE READER and $1 \alpha, 25-\left(\mathrm{OH}_{2} \mathrm{D}_{3}\right)$ was measured with the LC-MS/MS method by Nexera UHPLC (Oriental Yeast CO., LTD., Shiga, Japan).

\section{Measurement of urine creatinine, calcium and 8-hydroxy-2'-deoxyguanosine (8-0HdG)}

The concentrations of urine creatinine and calcium in the spot urine collected by bladder massage were assessed. Urine creatinine and calcium were measured with the enzyme method using the 7170 autoanalyzer (Oriental Yeast CO., LTD., Shiga, Japan), and the calcium creatinine ratio was evaluated. The concentration of urine $8-\mathrm{OHdG}$ was measured with New 8-OHdG Check ELISA by MTP300 Micro Plate Reader (Oriental Yeast CO., LTD., Shiga, Japan).

\section{Real-time quantitative reverse transcription-PCR analysis}

Total RNA was extracted from the kidney and intestine (duodenum) with ISOGEN (Nippon Gene). cDNA was synthesized using the SuperScript III First Strand System (Invitrogen). Real-time quantitative reverse transcriptionPCR (RT-PCR) was performed by incubating the reverse transcribed product with Taqman PCR Master Mix and a designed Taqman probe (ATP2B1: Mm01232254_m1, ATP2B4: Mm01285597_m1, $\mathrm{Na}^{+} / \mathrm{Ca}^{2+}$ exchanger 1 (NCX1): Mm01232254_m1, Transient Receptor Potential Vanilloid (TRPV) channel type6: Mm00499069_m1, renin: Mm02342887_mH, Applied Biosystems). RNA amounts are shown relative to the mRNA control (18s: 4319413E; Applied Biosystems). 
a.

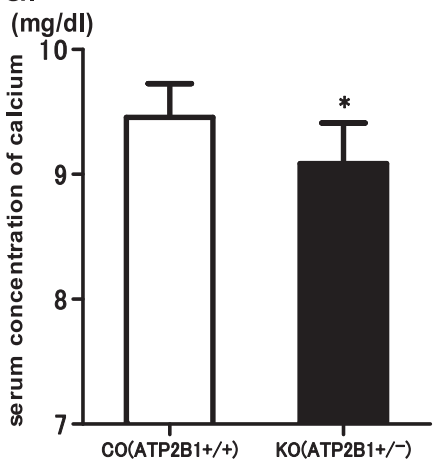

b.

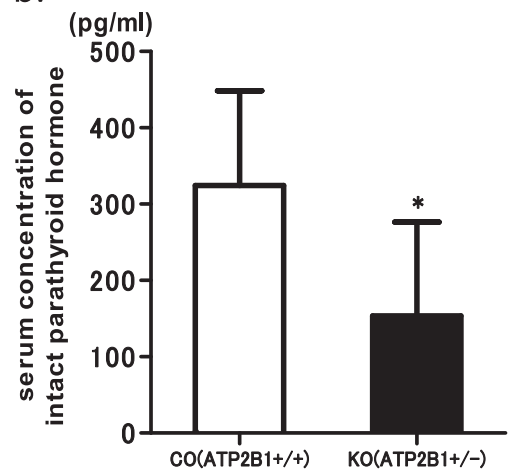

C.

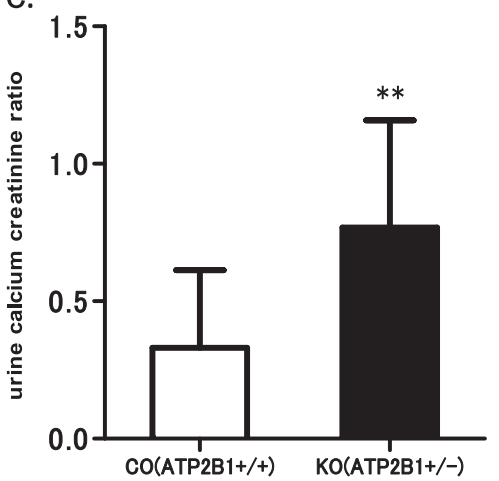

Fig. 1 Measurement of serum calcium, intact parathyroid hormone, and. urine calcium creatinine ratio. a Serum concentration of calcium in ATP2B1 $1^{+/-}$mice $(n=7)$ and ATP2B1 $1^{+/+}$mice $(n=8)$. b Serum concentration of intact parathyroid hormone in ATP2B $1^{+/-}$mice and $\mathrm{ATP} 2 \mathrm{~B} 1^{+/+}$mice $(n=9$ for each group). c Urine calcium and

\section{Assessment of bone mineral density and bone pathology}

Isolated femoral bone was assessed by peripheral quantitative computed tomography (pQCT) with XCT Research SA+ (Stratec Medizintechnik GmbH, Pforzheim, Germany) (Kureha-analyze center, Tokyo, Japan). Hematoxylin and eosin (HE) staining, tartrate-resistant acid (TRAP) staining, and von Kossa staining were performed. The number and properties of osteoblasts were confirmed by HE staining. The number and properties of osteoclasts were confirmed by TRAP staining.

\section{Statistical analysis}

For statistical analysis of differences between groups, the unpaired Student's $t$-test was used. All quantitative data are expressed as mean \pm SEM. $P$-values $<0.05$ were considered significant.

\section{Results}

\section{Generation of ATP2B1 ${ }^{+/-}$mice}

As we reported previously, ATP2B $1^{+/-}$mice were generated by mating ATP2B1 $1^{+/+}$mice: Male Tie2-Cre mice with ATP2B $1^{\text {loxp/loxp }}$ female mice. These mice were born and grew normally with no detectable abnormalities. Real-time quantitative-PCR analysis revealed approximately 70\% lower ATP2B1 mRNA levels in tissues (brain, heart, lung, aorta, kidney, liver, spleen skeletal muscle and intestine) from ATP2B1 ${ }^{+/-}$mice compared with in control mice. RT-PCR analysis demonstrated a deletion of exon 10 in ATP2B1 ${ }^{+/-}$ vascular smooth muscle cells. Expression of PMCA1 protein in kidneys from ATP2B1 $1^{+/-}$mice was significantly lower than that in control mice on Western blotting [10]. creatinine were measured in ATP2B $1^{+/-}(n=12)$ and ATP2B $1^{+/+}$ mice $(n=11)$. Data are mean \pm SEM. $t$-test $* p<0.05$ versus the control group, $* * p<0.01$ versus the control group. ATP2B1 1 mice exhibited hypocalcemia and decreased intact-PTH. Urine calcium creatinine ratio was increased in $\mathrm{ATP} 2 \mathrm{~B} 1 \pm$ mice

Table 1 Measurement of serum phosphorous and several calcium regulatory markers

\section{$\mathrm{CO}\left(\mathrm{ATP} 2 \mathrm{~B} 1^{+/+}\right) \quad \mathrm{KO}\left(\mathrm{ATP} 2 \mathrm{~B} 1^{+/-}\right)$}

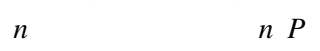

\begin{tabular}{llll}
\hline Phosphorus $(\mathrm{mg} / \mathrm{dL})$ & $7.7 \pm 0.4$ & $87.7 \pm 0.2$ & 9 NS \\
FGF23 $(\mathrm{pg} / \mathrm{mL})$ & $114 \pm 6$ & $999 \pm 5$ & $9 \mathrm{NS}$ \\
$1 \alpha .25-(\mathrm{OH})_{2} \mathrm{D}_{3}(\mathrm{pg} / \mathrm{mL})$ & $23.6 \pm 3.1$ & $820.2 \pm 3.2$ & $8 \mathrm{NS}$ \\
Osteocalcin $(\mathrm{ng} / \mathrm{mL})$ & $94 \pm 7$ & $8103 \pm 6$ & $8 \mathrm{NS}$ \\
\hline
\end{tabular}

Measurement of serum phosphorous and several calcium regulatory markers. Serum phosphorous, $1 \alpha .25-(\mathrm{OH})_{2} \mathrm{D}_{3}$,FGF23 and osteocalcin concentrations were not significantly different between the two groups. Data are mean \pm SEM. $t$-test $* p<0.05$ versus the control group

\section{Serum calcium, phosphorous and calcium regulatory markers}

The serum calcium concentration was significantly decreased in $\mathrm{ATP} 2 \mathrm{~B} 1^{+/-}$mice compared with in ATP2B1 $1^{+/+}$mice (Fig. 1a, $9.5 \pm 0.1$ versus $9.1 \pm 0.1, P<0.05$ ). On the other hand, the serum phosphorous concentration was not different between the two groups (Table 1). Based on the above results, we examined alteration of calcium regulatory markers. The serum intact-PTH concentration was significantly decreased in $\mathrm{ATP} 2 \mathrm{~B} 1^{+/-}$mice compared with in ATP2B1 $1^{+/+}$mice (Fig. 1b, $324.4 \pm 41.4$ versus $153.6 \pm 41.0, P<0.05$ ). However, $1 \alpha, 25-(\mathrm{OH})_{2} \mathrm{D}_{3}$ and FGF23 concentrations were not significantly different between the two groups (Table 1).

\section{Urinary excretion of calcium}

The urine calcium creatinine ratio was significantly increased in $\mathrm{ATP} 2 \mathrm{~B} 1^{+/-}$mice compared with in ATP2B $1^{+/+}$mice (Fig. 1c, $0.33 \pm 0.08$ versus $0.77 \pm 0.12$, $P<0.05)$. 

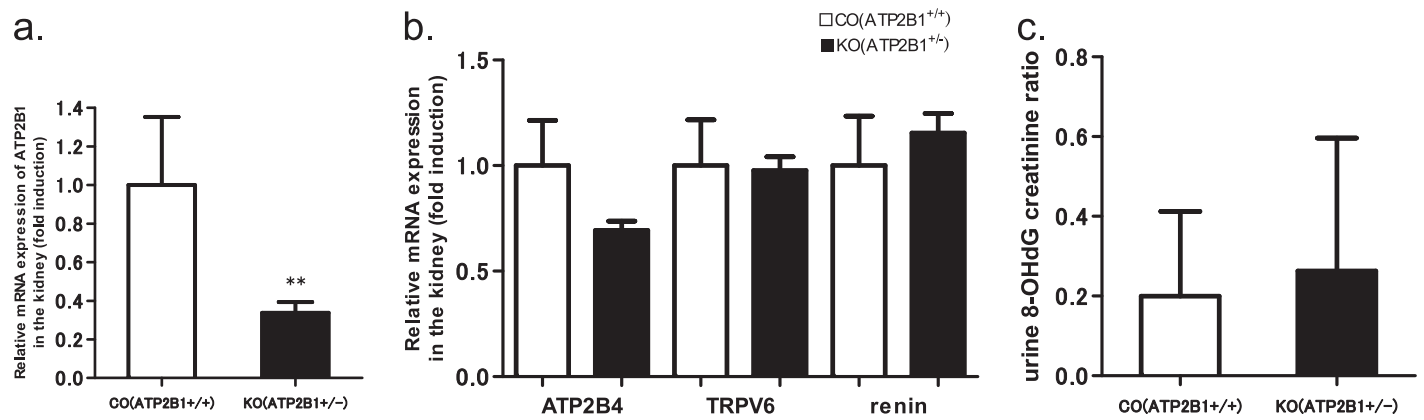

Fig. 2 Relative mRNA expression of ATP2B1, ATP2B4, TRPV6 and renin in the kidney, and urine $8-\mathrm{OHdG}$ creatinine ratio. Relative mRNA expression levels of (a) ATP2B1, b ATP2B4, TRPV6 and renin were determined in the kidney of ATP2B $1^{+/+}$and ATP2B1 $1^{+/-}$ mice ( $n=6$ for each group). ATP2B1 mRNA expression was

\section{Urinary oxidative-stress marker}

The urine 8 -OHdG creatinine ratio was not significantly different between the two groups (Fig. 2c).

\section{The mRNA expression of ATP2B1, other calcium transporters and renin in the kidney}

We performed qRT-PCR using kidney tissue from $\mathrm{ATP} 2 \mathrm{~B} 1^{+/-}$and $\mathrm{ATP} 2 \mathrm{~B} 1^{+/+}$mice to examine alterations in calcium regulator transporters and renin expression. The mRNA expression of $A T P 2 B 1$ was significantly decreased (Fig. 2a, $1.00 \pm 0.14$ versus $0.34 \pm 0.02, P<0.05$ ) in ATP2 $\mathrm{B}^{+/-}$mice compared with in ATP2B ${ }^{+/+}$mice. On the other hand, the mRNA expression of ATP2B4, TRPV6 and renin was not different between the two groups (Fig. 2b). Similarly, the urinary excretion of $8-\mathrm{OHdG}$ was not different between the groups (Fig. 2c).

\section{The mRNA expression of ATP2B1 and other calcium transporters in the small intestine}

We performed qRT-PCR using small intestine tissue from $\mathrm{ATP} 2 \mathrm{~B} 1^{+/-}$and ATP2B $1^{+/+}$mice to examine alterations in calcium regulator transporter expression. The mRNA expression of $A T P 2 B 1$ was significantly decreased (Fig. 3a, $1.00 \pm 0.12$ versus $0.56 \pm 0.0920, P<0.05$ ) in ATP2B $1^{+/-}$mice compared with in ATP2B $1^{+/+}$mice. On the other hand, the mRNA expression of TRPV6 and NCX1 was not different between the two groups (Fig. 3b).

\section{Bone mineral density and bone mass}

We performed pQCT using femoral bone of ATP2B $1^{+/-}$ and ATP2B $1^{+/+}$mice in order to clarify the effects of $A T P 2 B 1$ reduction on bone metabolism in the entire body. The bone mineral density was significantly increased in

decreased in the kidney of ATP2B1 $1^{+/-}$mice. The mRNA expression of ATP2B4, TRPV6 and renin was not different between the two groups. Urine $8-\mathrm{OHdG}$ and creatinine were measured in ATP2B $1^{+1-}$ $(n=11)$ and ATP2B $1^{+/+}$mice $(n=10)$. Urine 8 -OHdG creatinine ratio was not different between the two groups

ATP2B $1^{+/-}$mice compared with in $\mathrm{ATP} 2 \mathrm{~B} 1^{+/+}$mice (Fig. 4, 645.2 \pm 9.2 versus $689.0 \pm 12.9, P<0.05$ ). Consistent with the increase in bone mineral density, von Kossa staining of femoral bone revealed increased bone mass in ATP2B $1^{+/-}$mice (Fig. 4).

\section{Osteoblasts with eosinophilic cytoplasm and osteoclasts}

We performed HE staining using femoral bone of $\mathrm{ATP} 2 \mathrm{~B} 1^{+/-}$and $\mathrm{ATP} 2 \mathrm{~B} 1^{+/+}$mice to confirm the cell properties and number of osteoblasts. The number of osteoblasts with eosinophilic cytoplasm in the growth plate was significantly increased in ATP2B1 ${ }^{+/-}$mice compared with in ATP2B $1^{+/+}$mice (Fig. 5a, b, $9 \pm 3$ versus $33 \pm 8$, $P<0.05)$. This indicates that osteogenesis is promoted in ATP2 $1^{+/-}$mice. We performed TRAP staining using femoral bone of ATP2B1 $1^{+/-}$and ATP2B $1^{+/+}$mice to clarify the cell properties and number of osteoclasts. The number of osteoclasts was not different between the two groups (Fig. 5c, d).

\section{Discussion}

In the present study, we found that ATP2B $1^{+/-}$mice had decreased intact-PTH levels despite hypocalcemia. The expression of $A T P 2 B 1$ in the kidney and small intestine decreased, furthermore femoral bone mineral density and urinary calcium excretion increased. Thus, we confirmed that the altered expression of the ATP $2 B 1$ gene, which is thought to be responsible for regulating the intracellular calcium concentration, also affected the calcium metabolism throughout the entire body.

Ryan et al. [13] reported that the serum calcium concentration in small intestine-specific ATP2B1-deficient mice was not different from that in control mice. We previously confirmed that the vascular smooth muscle-specific 


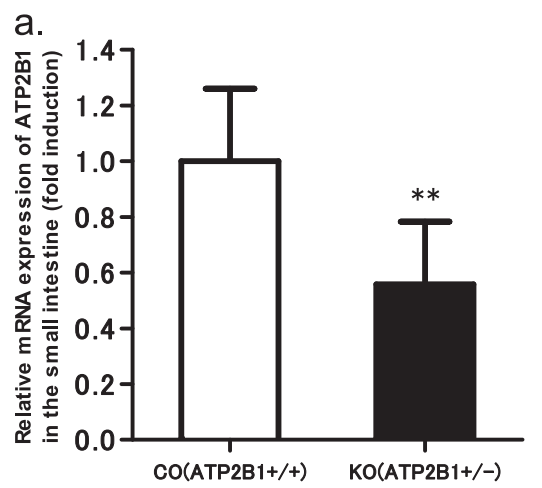

Fig. 3 Relative mRNA expression of calcium transporters in the small intestine. Relative mRNA expression levels of (a) ATP2B1 were determined in the small intestine of ATP2B $1^{+/+}$and ATP2B $1^{+/-}$mice ( $n=6$ for each group). ATP2B1 mRNA expression was decreased in ATP2B $1^{+/-}$mice. Relative mRNA expression levels of (b) NCX1 and

ATP2B1-deficient mice had no alterations in serum calcium levels (unpublished data). However, ATP2 $\mathrm{B}^{+/-}$mice exhibited hypocalcemia in the present study. As the parathyroid gland may be stimulated by the reduced calcium concentration [18], the hypocalcemia observed in ATP2B $1^{+-}$mice should be corrected by the increased PTH secretion as a compensatory mechanism. However, the PTH values in ATP2B $1^{+/-}$mice were lower than those in control mice. This suggests that serum PTH production was suppressed by knockout of $A T P 2 B 1$ in the parathyroid gland. We confirmed that ATP2B1 expression in all organs in $\mathrm{ATP} 2 \mathrm{~B} 1^{+/-}$mice was decreased, and that vascular smooth muscle intracellular $\mathrm{Ca}^{2+}$ concentrations were increased when ATP2B1 expression was decreased in VSMC. Similarly, ATP2B1 expression in the parathyroid gland may also decrease, increasing the intracellular $\mathrm{Ca}^{2+}$ concentration. Parathyroid cells have a pathway to reduce PTH secretion by elevating the intracellular $\mathrm{Ca}^{2+}$ concentration, which induces arachidonic acid (AA) through activation of cytosolic phospholipase A2 (cPLA2) [19-22]. Through the $\mathrm{Ca}^{2+}$-cPLA2-AA mechanisms, PTH secretion may be suppressed in ATP2B $1^{+/-}$mice. We attempted to verify the expression level of $A T P 2 B 1$ in the parathyroid gland in ATP2B $1^{+-}$mice, but isolation of the gland and evaluation of expression were difficult because of its small size [23].

There are some reports that suggest the relationship between PTH and blood pressure. Kalinowski et al. [24] reported that hPTH [1-34] and hPTHrP [1-34] activate NO production in endothelial cells, and experimental data suggested that PTH and PTHrp exert their vasorelaxant action via cAMP-dependent inhibition of L-type $\mathrm{Ca}^{2+}$ channel currents in VSMC $[25,26]$. Thus, the decreased PTH secretion may cause decreased $\mathrm{NO}$ production, as observed in ATP2B $1^{+-}$mice [10]. On the other hand, there are numerous reports demonstrating the vasodilatory effects of exogenously administered PTH. Saglikes et al. [27] found b.

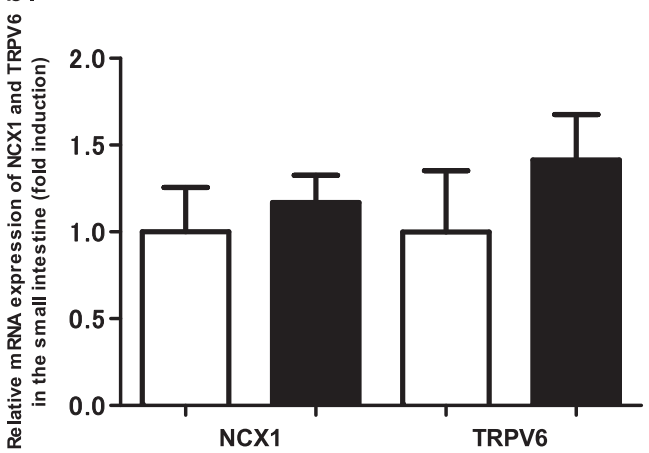

TRPV6 were examined in the small intestine of ATP2B1 $1^{+/+}(n=6)$ and ATP2B $1^{+/-}$mice $(n=6)$. The mRNA expression of TRPV6 and NCX1 was not different between the two groups. Data are mean \pm SEM. $t$-test $* p<0.05$ versus the control group

that PTH blunts the vasoconstrictor effects of naturally occurring agonists, such as norepinephrine and angiotensin II, and this action is mediated via the production of vasodilating prostaglandins. Thus, the decreased PTH secretion may cause hypertension via decreased vasodilators in $\mathrm{ATP} 2 \mathrm{~B} 1^{+/-}$mice.

The relationship between hypercalciuria and blood pressure was also reported. Kamijo et al. [28] noted the importance of hypercalciuria in spontaneously hypertensive rats. In this study, we observed a significant increase in urinary calcium excretion, and a significant decrease in ATP2B1 expression in the kidney in ATP2B $1^{+/-}$hypertensive mice $[10,15]$. On the other hand, the expression of ATP2B4, NCX1 was not altered. As PMCA1 exists on the basolateral side of the organ, it may directly or indirectly influence the serum calcium concentration. Through PMCA or NCX1, $\mathrm{Ca}^{2+}$ is thought to be extruded at the basolateral side by binding to $\mathrm{CaBP}_{28 \mathrm{k}}$ and/or $\mathrm{CaBP}_{9 \mathrm{k}}[29,30]$ in the late distal convoluted tubule (DCT) and the connecting tubule (CNT), which is regulated by hormones, including PTH and active $1 \alpha, 25-(\mathrm{OH})_{2} \mathrm{D}_{3}$ [31-33]. The result that ATP2B4 has not altered suggests that ATP2B1 is more important than ATP2B4 in calcium regulation. Then, it is suggested that decreased expression of ATP2B1 in the kidney is mainly associated with increased urinary calcium excretion.

Pointer et al. [34] also reported that calcium excretion is associated with lower renal cortical interstitial fluid calcium, which is associated with high blood pressure, as observed in Dahl salt-sensitive (DS) rats. Furthermore, Tojo et al. $[35,36]$ found that eNOS in the renal vasculature was significantly decreased in the DS rats. Thus, a similar mechanism may be involved in the hypertension exhibited by $\mathrm{ATP} 2 \mathrm{~B} 1^{+/}$mice because eNOS expression was decreased, as described in our previous study [10]. One the other hand, the expression of renin in the kidney and urine 8 -OHdG creatinine ratio were not different between two 
Fig. 4 Von Kossa staining and bone mineral density in femoral bone by peripheral quantitative computed tomography (pQCT) (mg/cm3). Von Kossa staining and bone mineral density in a ATP $2 \mathrm{~B}^{+/+}$and b ATP2B $1^{+/-}$ mice ( $n=8$ for each group). Data are mean \pm SEM. $t$-test $* p<$ 0.05 versus the control group. Bone mineral density and bone mass were significantly increased in ATP2B $1^{+/-}$mice compared with in ATP2B1 $1^{+/+}$ mice a. $\operatorname{CO}\left(\mathrm{ATP}_{2} \mathrm{~B} 1^{+/+}\right)$

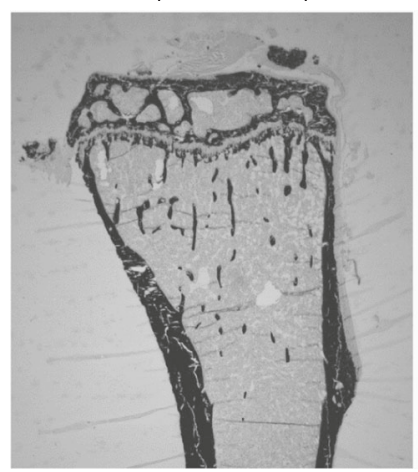

b. $\mathrm{KO}\left(\mathrm{ATP}_{2} \mathrm{~B} 1^{++-}\right)$

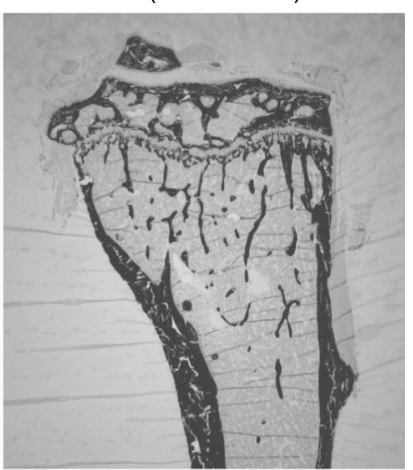

Bone mineral density $\left(\mathrm{mg} / \mathrm{cm}^{3}\right)$

Diaphyseal region

Metaphyseal region
$645.2 \pm 9.2$

$449.7 \pm 14.5$
$P$

$689.0 \pm 12.9$

0.0154

$490.0 \pm 18.2$ groups, which suggest that renal RAS systems is not important to blood pressure contorl in ATP2B $1^{+/}$mice.

As ATP2B $1^{+/-}$mice exhibited hypocalcemia, we pursued other mechanisms related with calcium metabolism. The absorption of calcium in the small intestine may play an important role in calcium homeostasis. Intracellular $\mathrm{Ca}^{2+}$ binding proteins, such as $\mathrm{CaBP}_{9 \mathrm{k}}$, facilitate the movement of $\mathrm{Ca}^{2+}$ across enterocytic cells [37], and basal-lateral PMCA [38] and NCX [39] assist in the removal of $\mathrm{Ca}^{2+}$ from the cell to the extracellular fluid. In this study, we confirmed that $A T P 2 B 1$ was significantly decreased and $\mathrm{CaBP}_{9 \mathrm{k}}$ was significantly increased in the small intestine of $\mathrm{ATP} 2 \mathrm{~B} 1^{+/-}$mice. However, the expression levels of TRPV6 and NCX1 calcium regulatory proteins were not altered. Therefore, PMCA1 plays an important role in calcium metabolism in the small intestine, and its uptake into the blood is likely decreased due to the reduced ATP2BI expression level. However, Ryan et al. [13] reported that small intestine-specific ATP2B1-deficient mice exhibited decreased bone mineral density without altered PTH level or serum calcium concentration. ATP2B1 in the small intestine may have little effect on serum calcium concentration, but why bone mineral density decreased in intestine-specific ATP2B1 KO mice remains unknown. Thus, we also examined alterations of bone phenotypes in ATP2B $1^{+/-}$mice.

In $\mathrm{ATP} 2 \mathrm{~B} 1^{+/-}$mice, the bone mineral density was markedly increased. Moreover, we confirmed that bone mass increased in ATP2B $1^{+-}$mice by von Kossa staining. In addition, an increased number of osteoblasts with eosinophilic cytoplasm was found in ATP2B $1^{+/-}$mice, suggesting that bone production was increased [40]. However, there was no significant difference in the shape or number of osteoclasts. In the ATP2B $1^{+-}$mice, the bone mass was increased and PTH secretion was decreased. The decreased
PTH levels were reasonable for the increased bone mass observed in the present study because it is known that PTH activates osteoclasts and suppresses the proliferation of osteoblasts [41-43]. However, despite the decreased PTH secretion, there was an increase in osteoblasts and no change in osteoclasts. This suggests that $A T P 2 B 1$ is directly involved in bone formation and bone resorption independently of PTH. As there were alterations in PTH values and bone density in ATP2B $1^{+/-}$mice, we predicted that $1 \alpha, 25$ $(\mathrm{OH})_{2} \mathrm{D}_{3}$ was also changed. However there were no significant changes in $1 \alpha, 25-(\mathrm{OH})_{2} \mathrm{D}_{3}$ concentrations.

$A T P 2 B 1$ gene polymorphisms are known to affect the expression level of $A T P 2 B 1$ in human umbilical cord blood vessels. Indeed, patients with a polymorphism causing decreased $A T P 2 B 1$ expression exhibited high blood pressure [2]. Similarly, in whole-body heterozygous ATP2B1deficient mice in the previous study, expression of $A T P 2 B 1$ was decreased and blood pressure was elevated due to decreased eNOS activity and NO production [10]. This study also confirmed that ATP2B $1^{+/-}$mice had hypocalcemia. The absorption of calcium in the kidney was decreased and suppression of bone resorption was suggested in these hypertensive mice. These effects were considered to be partly due to the reduction in PTH secretion by the $A T P 2 B 1$ knockout, and these results suggested that reduced PTH secretion and hypercalciuria are associated with elevated blood pressure via $\mathrm{NO}$ reduction in ATP2B $1^{+/-}$mice.

There are several limitations in this study. As the parathyroid gland was too small, we were unable to clarify the mechanisms of ATP2B1 on PTH secretion using the parathyroid gland in detail. This needs to be evaluated in a future study. Although this study helped to elucidate the reason for NO reduction in $\mathrm{ATP} 2 \mathrm{~B} 1^{+/-}$mice, further study is needed in the future. 

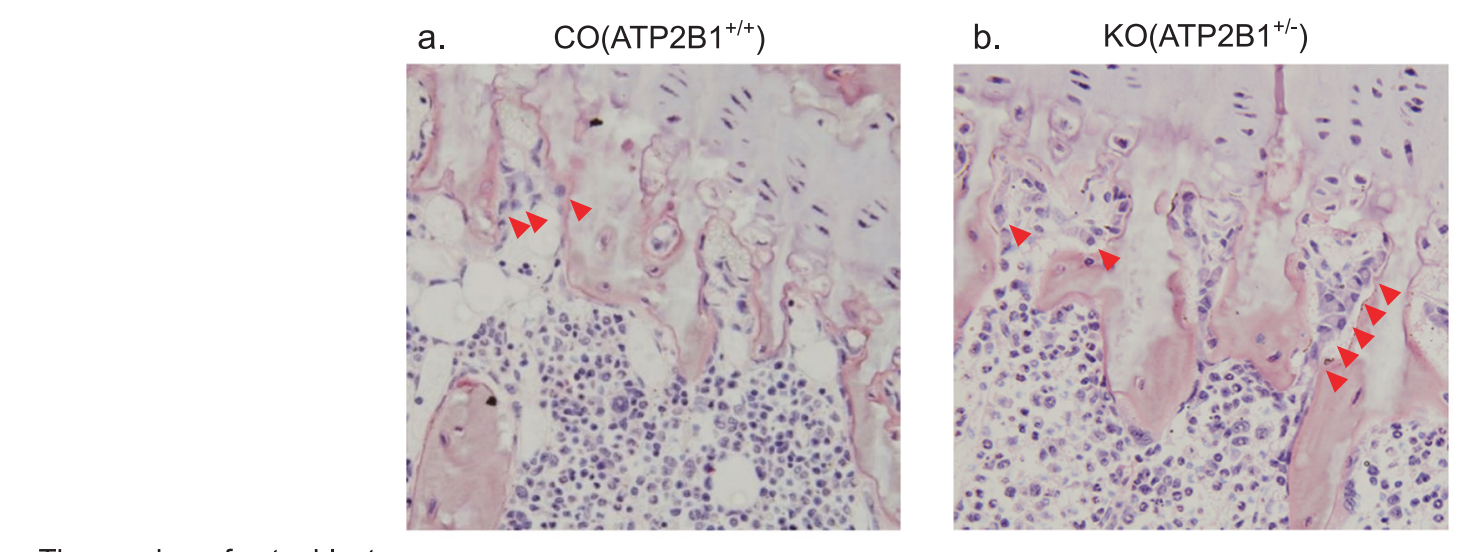

The number of osteoblasts with eosinophilic cytoplasm

$9 \pm 3$

c. $\quad \mathrm{CO}\left(\mathrm{ATP} 2 \mathrm{~B} 1^{+/+}\right)$

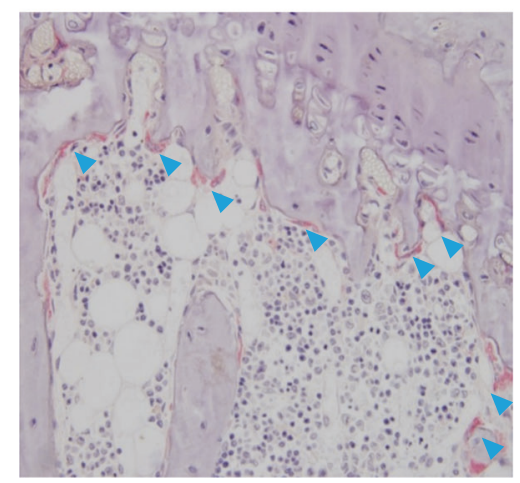

$50 \pm 8$
$33 \pm 8$

\section{d. $\quad \mathrm{KO}\left(\mathrm{ATP} 2 \mathrm{~B} 1^{+/-}\right)$}

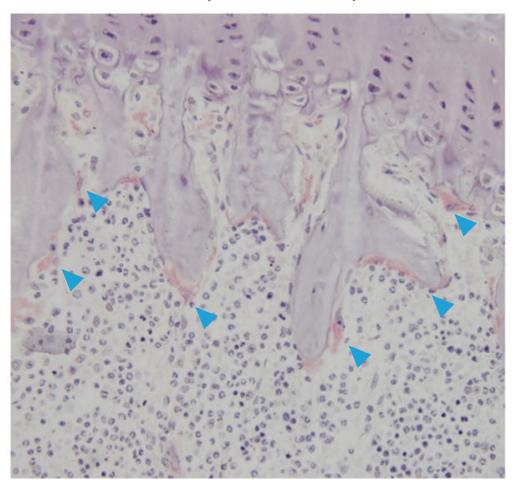

$36 \pm 8$
$\mathrm{P}$

0.0399
The number of osteoclasts

Fig. 5 The number of osteoblasts with eosinophilic cytoplasm on HE staining, and the number of osteoclasts on TRAP staining. HE staining and the number of osteoblasts with eosinophilic cytoplasm in (a) ATP2 $\mathrm{B} 1^{+/+}$mice and (b) ATP2 $\mathrm{B} 1^{+/-}$mice ( $n=3$ for each group). TRAP staining and the number of osteoclasts in (c) ATP2B $1^{+l+}$ mice

In conclusion, systemic heterozygous $A T P 2 B 1$-null mice are thought to be a useful model for examining the pathology of calcium metabolism and hypertension. The ATP2BI gene is important for not only intra-cellular calcium regulation but also for calcium homeostasis and blood pressure.

Acknowledgements This work was supported by Grants-in -Aid for Scientific Research (JP25461249, JP16K09648) from the Ministry of Education, Culture, Sports, Science, and Technology, Japan Society for the Promotion of Science, japan, a Uehara Memorial Foundation grant, the Salt Science Research Foundation (1733), and Grants for Research from Yokohama City University, Japan.

\section{Compliance with ethical standards}

Conflict of interest $\mathrm{NH}$ received a research grant from Pfizer, and SU received lecture fees from Takeda, Behringer, Daiichi-Sankyo, MSD, received manuscript fees from Sunmark publishing, and received scholarship donations from Takeda, Pfizer, Asteras, Daiichi-Sankyo, Behringer and AstraZeneka. KT received research grants from AstraZeneca, Ono Pharmaceutical and Tsumura. NH and SU have been name as the inventors on a patent based on work on ATP2B1 SNPs and hypertension. The remaining authors declare no conflicts of interest. and (d) ATP2B $1^{+/-}$mice ( $n=3$ for each group). Data are mean \pm SEM. $t$-test ${ }^{*} p<0.05$ versus the control group. The number of osteoblasts with eosinophilic cytoplasm in the growth plate was significantly increased in ATP2 $\mathrm{B}^{+/-}$mice. The number of osteoclasts was not different between the two groups

Open Access This article is licensed under a Creative Commons Attribution-NonCommercial-NoDerivatives 4.0 International License, which permits any non-commercial use, sharing, distribution and reproduction in any medium or format, as long as you give appropriate credit to the original author(s) and the source, and provide a link to the Creative Commons license. You do not have permission under this license to share adapted material derived from this article or parts of it. The images or other third party material in this article are included in the article's Creative Commons license, unless indicated otherwise in a credit line to the material. If material is not included in the article's Creative Commons license and your intended use is not permitted by statutory regulation or exceeds the permitted use, you will need to obtain permission directly from the copyright holder. To view a copy of this license, visit http://creativecommons.org/licenses/by-nc-nd/4.0/.

\section{References}

1. Kohara K, Tabara Y, Nakura J, Imai Y, Ohkubo T, Hata A, Soma M, Nakayama T, Umemura S, Hirawa N, Ueshima H, Kita Y, Ogihara T, Katsuya T, Takahashi N, Tokunaga K, Miki T. Identification of hypertension-susceptibility genes and pathways by a systemic multiple candidate gene approach: the millennium genome project for hypertension. Hypertens Res. 2008;31:203-12. 
2. Tabara Y, Kohara K, Kita Y, Hirawa N, Katsuya T, Ohkubo T, Hiura Y, Tajima A, Morisaki T, Miyata T, Nakayama T, Takashima N, Nakura J, Kawamoto R, Takahashi N, Hata A, Soma M, Imai Y, Kokubo Y, Okamura T, Tomoike H, Iwai N, Ogihara T, Inoue I, Tokunaga K, Johnson T, Caulfield M, Munroe P, Umemura S, Ueshima H, Miki T. Common variants in the ATP2B1 gene are associated with susceptibility to hypertension: the Japanese Millennium Genome Project. Hypertension. 2010;56:973-80.

3. Levy D, Ehret GB, Rice K, Verwoert GC, Launer LJ, Dehghan A, Glazer NL, Morrison AC, Johnson AD, Aspelund T, Aulchenko Y, Lumley T, Kottgen A, Vasan RS, Rivadeneira F, Eiriksdottir G, Guo X, Arking DE, Mitchell GF, Mattace-Raso FU, Smith AV, Taylor K, Scharpf RB, Hwang SJ, Sijbrands EJ, Bis J, Harris TB, Ganesh SK, O'Donnell CJ, Hofman A, Rotter JI, Coresh J, Benjamin EJ, Uitterlinden AG, Heiss G, Fox CS, Witteman JC, Boerwinkle E, Wang TJ, Gudnason V, Larson MG, Chakravarti A, Psaty BM, van Duijn CM. Genome-wide association study of blood pressure and hypertension. Nat Genet. 2009;41:677-87.

4. Cho YS, Go MJ, Kim YJ, Heo JY, Oh JH, Ban HJ, Yoon D, Lee MH, Kim DJ, Park M, Cha SH, Kim JW, Han BG, Min H, Ahn Y, Park MS, Han HR, Jang HY, Cho EY, Lee JE, Cho NH, Shin C, Park T, Park JW, Lee JK, Cardon L, Clarke G, McCarthy MI, Lee JY, Lee JK, Oh B, Kim HL. A large-scale genome-wide association study of Asian populations uncovers genetic factors influencing eight quantitative traits. Nat Genet. 2009;41:527-34.

5. Ehret GB, Munroe PB, Rice KM, Bochud M, Johnson AD, Chasman DI, Smith AV, Tobin MD, Verwoert GC, Hwang SJ, Pihur V, Vollenweider P, O'Reilly PF, Amin N, Bragg-Gresham JL, Teumer A, Glazer NL, Launer L, Zhao JH, Aulchenko Y, Heath S, Sober S, Parsa A, Luan J, Arora P, Dehghan A, Zhang F, Lucas G, Hicks AA, Jackson AU, Peden JF, Tanaka T, Wild SH, Rudan I, Igl W, Milaneschi Y, Parker AN, Fava C, Chambers JC, Fox ER, Kumari M, Go MJ, van der Harst P, Kao WH, Sjogren M, Vinay DG, Alexander M, Tabara Y, Shaw-Hawkins S, Whincup PH, Liu Y, Shi G, Kuusisto J, Tayo B, Seielstad M, Sim $\mathrm{X}$, Nguyen KD, Lehtimaki T, Matullo G, Wu Y, Gaunt TR, Onland-Moret NC, Cooper MN, Platou CG, Org E, Hardy R, Dahgam S, Palmen J, Vitart V, Braund PS, Kuznetsova T, Uiterwaal CS, Adeyemo A, Palmas W, Campbell H, Ludwig B, Tomaszewski M, Tzoulaki I, Palmer ND, Aspelund T, Garcia M, Chang YP, O'Connell JR, Steinle NI, Grobbee DE, Arking DE, Kardia SL, Morrison AC, Hernandez D, Najjar S, McArdle WL, Hadley D, Brown MJ, Connell JM, Hingorani AD, Day IN, Lawlor DA, Beilby JP, Lawrence RW, Clarke R, Hopewell JC, Ongen H, Dreisbach AW, Li Y, Young JH, Bis JC, Kahonen M, Viikari J, Adair LS, Lee NR, Chen MH, Olden M, Pattaro C, Bolton JA, Kottgen A, Bergmann S, Mooser V, Chaturvedi N, Frayling TM, Islam M, Jafar TH, Erdmann J, Kulkarni SR, Bornstein SR, Grassler J, Groop L, Voight BF, Kettunen J, Howard P, Taylor A, Guarrera S, Ricceri F, Emilsson V, Plump A, Barroso I, Khaw KT, Weder AB, Hunt SC, Sun YV, Bergman RN, Collins FS, Bonnycastle LL, Scott LJ, Stringham HM, Peltonen L, Perola M, Vartiainen E, Brand SM, Staessen JA, Wang TJ, Burton PR, Soler Artigas M, Dong Y, Snieder H, Wang X, Zhu H, Lohman KK, Rudock ME, Heckbert SR, Smith NL, Wiggins KL, Doumatey A, Shriner D, Veldre G, Viigimaa M, Kinra S, Prabhakaran D, Tripathy V, Langefeld CD, Rosengren A, Thelle DS, Corsi AM, Singleton A, Forrester T, Hilton G, McKenzie CA, Salako T, Iwai N, Kita Y, Ogihara T, Ohkubo T, Okamura T, Ueshima H, Umemura S, Eyheramendy S, Meitinger T, Wichmann HE, Cho YS, Kim HL, Lee JY, Scott J, Sehmi JS, Zhang W, Hedblad B, Nilsson P, Smith GD, Wong A, Narisu N, Stancakova A, Raffel LJ, Yao J, Kathiresan S, O'Donnell CJ, Schwartz SM, Ikram MA, Longstreth WT Jr., Mosley TH, Seshadri S, Shrine NR, Wain LV, Morken MA, Swift AJ, Laitinen J, Prokopenko I, Zitting P, Cooper JA, Humphries SE, Danesh J,
Rasheed A, Goel A, Hamsten A, Watkins H, Bakker SJ, van Gilst WH, Janipalli CS, Mani KR, Yajnik CS, Hofman A, MattaceRaso FU, Oostra BA, Demirkan A, Isaacs A, Rivadeneira F, Lakatta EG, Orru M, Scuteri A, Ala-Korpela M, Kangas AJ, Lyytikainen LP, Soininen P, Tukiainen T, Wurtz P, Ong RT, Dorr M, Kroemer HK, Volker U, Volzke H, Galan P, Hercberg S, Lathrop M, Zelenika D, Deloukas P, Mangino M, Spector TD, Zhai G, Meschia JF, Nalls MA, Sharma P, Terzic J, Kumar MV, Denniff M, Zukowska-Szczechowska E, Wagenknecht LE, Fowkes FG, Charchar FJ, Schwarz PE, Hayward C, Guo X, Rotimi C, Bots ML, Brand E, Samani NJ, Polasek O, Talmud PJ, Nyberg F, Kuh D, Laan M, Hveem K, Palmer LJ, van der Schouw YT, Casas JP, Mohlke KL, Vineis P, Raitakari O, Ganesh SK, Wong TY, Tai ES, Cooper RS, Laakso M, Rao DC, Harris TB, Morris RW, Dominiczak AF, Kivimaki M, Marmot MG, Miki T, Saleheen D, Chandak GR, Coresh J, Navis G, Salomaa V, Han BG, Zhu X, Kooner JS, Melander O, Ridker PM, Bandinelli S, Gyllensten UB, Wright AF, Wilson JF, Ferrucci L, Farrall M, Tuomilehto J, Pramstaller PP, Elosua R, Soranzo N, Sijbrands EJ, Altshuler D, Loos RJ, Shuldiner AR, Gieger C, Meneton P, Uitterlinden AG, Wareham NJ, Gudnason V, Rotter JI, Rettig R, Uda M, Strachan DP, Witteman JC, Hartikainen AL, Beckmann JS, Boerwinkle E, Vasan RS, Boehnke M, Larson MG, Jarvelin MR, Psaty BM, Abecasis GR, Chakravarti A, Elliott P, van Duijn CM, Newton-Cheh C, Levy D, Caulfield MJ, Johnson T. Genetic variants in novel pathways influence blood pressure and cardiovascular disease risk. Nature. 2011;478:103-9.

6. Guerini D, Pan B, Carafoli E. Expression, purification, and characterization of isoform 1 of the plasma membrane $\mathrm{Ca} 2+$ pump: focus on calpain sensitivity. J Biol Chem. 2003;278:38141-8.

7. Strehler EE, Zacharias DA. Role of alternative splicing in generating isoform diversity among plasma membrane calcium pumps. Physiol Rev. 2001;81:21-50.

8. Carafoli E. Biogenesis: plasma membrane calcium ATPase: 15 years of work on the purified enzyme. FASEB J. 1994;8:993-1002.

9. Kato N, Takeuchi F, Tabara Y, Kelly TN, Go MJ, Sim X, Tay WT, Chen CH, Zhang Y, Yamamoto K, Katsuya T, Yokota M, Kim YJ, Ong RT, Nabika T, Gu D, Chang LC, Kokubo Y, Huang W, Ohnaka K, Yamori Y, Nakashima E, Jaquish CE, Lee JY, Seielstad M, Isono M, Hixson JE, Chen YT, Miki T, Zhou X, Sugiyama T, Jeon JP, Liu JJ, Takayanagi R, Kim SS, Aung T, Sung YJ, Zhang X, Wong TY, Han BG, Kobayashi S, Ogihara T, Zhu D, Iwai N, Wu JY, Teo YY, Tai ES, Cho YS, He J. Metaanalysis of genome-wide association studies identifies common variants associated with blood pressure variation in east Asians. Nat Genet. 2011;43:531-8.

10. Fujiwara A, Hirawa N, Fujita M, Kobayashi Y, Okuyama Y, Yatsu K, Katsumata M, Yamamoto Y, Ichihara N, Saka S, Toya Y, Yasuda G, Goshima Y, Tabara Y, Miki T, Ueshima H, Ishikawa $\mathrm{Y}$, Umemura S. Impaired nitric oxide production and increased blood pressure in systemic heterozygous ATP2B1 null mice. J Hypertens. 2014;32:1415-23. discussion 1423

11. Kobayashi Y, Hirawa N, Tabara Y, Muraoka H, Fujita M, Miyazaki N, Fujiwara A, Ichikawa Y, Yamamoto Y, Ichihara N, Saka S, Wakui H, Yoshida S, Yatsu K, Toya Y, Yasuda G, Kohara K, Kita Y, Takei K, Goshima Y, Ishikawa Y, Ueshima H, Miki T, Umemura S. Mice lacking hypertension candidate gene ATP2B1 in vascular smooth muscle cells show significant blood pressure elevation. Hypertension. 2012;59:854-60.

12. Okuyama Y, Hirawa N, Fujita M, Fujiwara A, Ehara Y, Yatsu K, Sumida K, Kagimoto M, Katsumata M, Kobayashi Y, Saka S, Umemura S, Tamura K. The effects of anti-hypertensive drugs and the mechanism of hypertension in vascular smooth muscle cell-specific ATP2B1 knockout mice. Hypertens Res. 2018;41:80-87. 
13. Ryan ZC, Craig TA, Filoteo AG, Westendorf JJ, Cartwright EJ, Neyses L, Strehler EE, Kumar R. Deletion of the intestinal plasma membrane calcium pump, isoform 1, Atp2b1, in mice is associated with decreased bone mineral density and impaired responsiveness to 1, 25-dihydroxyvitamin D3. Biochem Biophys Res Commun. 2015;467:152-6.

14. Hoenderop JG, Nilius B, Bindels RJ. Calcium absorption across epithelia. Physiol Rev. 2005;85:373-22.

15. Okunade GW, Miller ML, Pyne GJ, Sutliff RL, O’Connor KT, Neumann JC, Andringa A, Miller DA, Prasad V, Doetschman T, Paul RJ, Shull GE. Targeted ablation of plasma membrane Ca2 +-ATPase (PMCA) 1 and 4 indicates a major housekeeping function for PMCA1 and a critical role in hyperactivated sperm motility and male fertility for PMCA4. J Biol Chem. 2004;279:33742-50.

16. de Lange WJ, Halabi CM, Beyer AM, Sigmund CD. Germ line activation of the Tie2 and SMMHC promoters causes noncellspecific deletion of floxed alleles. Physiol Genom. 2008;35:1-4.

17. Kisanuki YY, Hammer RE, Miyazaki J, Williams SC, Richardson JA, Yanagisawa M. Tie2-Cre transgenic mice: a new model for endothelial cell-lineage analysis in vivo. Dev Biol. 2001;230:230-42.

18. Scott KR, Fox J. Comparison of hypotensive response following intravenous injection of parathyroid hormone 1-84 and 1-34 in conscious rats. Calcif Tissue Int. 2006;79:389-94.

19. Bourdeau A, Souberbielle JC, Bonnet P, Herviaux P, Sachs C, Lieberherr M. Phospholipase-A2 action and arachidonic acid metabolism in calcium-mediated parathyroid hormone secretion. Endocrinology. 1992;130:1339-44.

20. Bourdeau A, Moutahir M, Souberbielle JC, Bonnet P, Herviaux P, Sachs C, Lieberherr M. Effects of lipoxygenase products of arachidonate metabolism on parathyroid hormone secretion. Endocrinology. 1994;135:1109-12.

21. Kifor O, MacLeod RJ, Diaz R, Bai M, Yamaguchi T, Yao T, Kifor I, Brown EM. Regulation of MAP kinase by calciumsensing receptor in bovine parathyroid and CaR-transfected HEK293 cells. Am J Physiol Ren Physiol. 2001;280:F291-302.

22. Almaden Y, Canalejo A, Ballesteros E, Anon G, Canadillas S, Rodriguez M. Regulation of arachidonic acid production by intracellular calcium in parathyroid cells: effect of extracellular phosphate. J Am Soc Nephrol. 2002;13:693-8.

23. Gunther T, Chen ZF, Kim J, Priemel M, Rueger JM, Amling M, Moseley JM, Martin TJ, Anderson DJ, Karsenty G. Genetic ablation of parathyroid glands reveals another source of parathyroid hormone. Nature. 2000;406:199-203.

24. Kalinowski L, Dobrucki LW, Malinski T. Nitric oxide as a second messenger in parathyroid hormone-related protein signaling. J Endocrinol. 2001;170:433-40.

25. Philbrick WM, Wysolmerski JJ, Galbraith S, Holt E, Orloff JJ, Yang KH, Vasavada RC, Weir EC, Broadus AE, Stewart AF. Defining the roles of parathyroid hormone-related protein in normal physiology. Physiol Rev. 1996;76:127-73.

26. Schluter KD, Piper HM. Cardiovascular actions of parathyroid hormone and parathyroid hormone-related peptide. Cardiovasc Res. 1998;37:34-41.
27. Saglikes Y, Massry SG, Iseki K, Nadler JL, Campese VM. Effect of PTH on blood pressure and response to vasoconstrictor agonists. Am J Physiol. 1985;248:F674-81.

28. Kamijo T, Gonzalez JM, Jost LJ, Barrios R, Suki WN. Renal abnormality of calcium handling in spontaneously hypertensive rats. Kidney Int Suppl. 1996;55:S166-8.

29. Boros S, Bindels RJ, Hoenderop JG. Active $\mathrm{Ca}(2+)$ reabsorption in the connecting tubule. Pflug Arch: Eur J Physiol. 2009;458:99-109.

30. Hoenderop JG, Nilius B, Bindels RJ. Molecular mechanism of active $\mathrm{Ca}^{2+}$ reabsorption in the distal nephron. Annu Rev Physiol. 2002;64:529-49.

31. Hoenderop JG, Dardenne O,Van Abel M,Van Der Kemp AW,Van Os CH, St-Arnaud R, Bindels RJ. Modulation of renal $\mathrm{Ca} 2+$ transport protein genes by dietary $\mathrm{Ca} 2+$ and 1,25-dihydroxyvitamin D3 in 25-hydroxyvitamin D3-1alpha-hydroxylase knockout mice. FASEB J. 2002;16:1398-406.

32. van Abel M, Hoenderop JG, van der Kemp AW, Friedlaender MM, van Leeuwen JP, Bindels RJ. Coordinated control of renal $\mathrm{Ca}(2+)$ transport proteins by parathyroid hormone. Kidney Int. 2005;68:1708-21.

33. Lambers TT, Bindels RJ, Hoenderop JG. Coordinated control of renal $\mathrm{Ca}^{2+}$ handling. Kidney Int. 2006;69:650-4.

34. Pointer MA, Eley S, Anderson L, Waters B, Royall B, Nichols S, Wells C. Differential effect of renal cortical and medullary interstitial fluid calcium on blood pressure regulation in salt-sensitive hypertension. Am J Hypertens. 2015;28:1049-55.

35. Toda N, Arakawa K. Salt-induced hemodynamic regulation mediated by nitric oxide. J Hypertens. 2011;29:415-24.

36. Tojo A, Onozato ML, Kobayashi N, Goto A, Matsuoka H, Fujita T. Angiotensin II and oxidative stress in Dahl Salt-sensitive rat with heart failure. Hypertension. 2002;40:834-9.

37. Wasserman RH, Fullmer CS. Vitamin D and intestinal calcium transport: facts, speculations and hypotheses. J Nutr. 1995; 125:1971s-79s.

38. Borke JL, Caride A, Verma AK, Penniston JT, Kumar R. Cellular and segmental distribution of $\mathrm{Ca} 2(+)$-pump epitopes in rat intestine. Pflug Arch: Eur J Physiol. 1990;417:120-2.

39. Philipson KD, Nicoll DA. Sodium-calcium exchange: a molecular perspective. Annu Rev Physiol. 2000;62:111-33.

40. Stacey EM, Royster WS. Histology for Pathologists. 4th ed. Lippincott Williams \& Wilkins, Philadelphia, USA 2012.

41. Chen Q, Kaji H, Iu MF, Nomura R, Sowa H, Yamauchi M, Tsukamoto T, Sugimoto T, Chihara K. Effects of an excess and a deficiency of endogenous parathyroid hormone on volumetric bone mineral density and bone geometry determined by peripheral quantitative computed tomography in female subjects. J Clin Endocrinol Metab. 2003;88:4655-8.

42. Chan FK, Tiu SC, Choi KL, Choi CH, Kong AP, Shek CC. Increased bone mineral density in patients with chronic hypoparathyroidism. J Clin Endocrinol Metab. 2003;88:3155-9.

43. Duan Y, De Luca V, Seeman E. Parathyroid hormone deficiency and excess: similar effects on trabecular bone but differing effects on cortical bone. J Clin Endocrinol Metab. 1999;84:718-22. 